\title{
Development of a methodological approach to assessing tourism potential, considering the recreational needs of the population
}

\author{
Elena O. Ushakova ${ }^{1,2}$, and Marina E. Tsoy ${ }^{1, *}$ \\ ${ }^{1}$ Novosibirsk State Technical University \\ ${ }^{2}$ Siberian State University of Geosystems and Technologies
}

\begin{abstract}
The current situation in the world market of tourist services is characterized by several restrictions concerning both the impossibility of traveling to some countries and tourist formalities aimed at observing the safety measures of tourists. In addition, the structure of tourists' needs has changed significantly, in connection with which the directions of "green" nature-oriented tourism have become actualized, contributing to the implementation of the concept of sustainable tourism development. In this regard, it is required to assess and re-evaluate the tourist potential of local territories and its development, considering the recreational needs of the local population. The article presents a methodological approach to assessing the tourist potential of local territories, considering the recreational needs of the population. The approach is based on the synthesis of methods for assessing the tourist-recreational potential of local territories and the real needs of tourist-recreational services among the population of the region. The methods of recreational-geographical, marketing, cluster approaches, as well as economic and mathematical modeling and cross-classification were used for methodology forming. The proposed methodological approach is in demand by regional and local authorities, tour operators and investors to objectively assess the tourist potential of local territories, considering the recreational needs of the population and the priorities of tourism development.
\end{abstract}

\section{Introduction}

The modern socio-economic situation in many large regions of the world, including the Russian Federation, is characterized by a significant decrease in indicators in almost all spheres of activity, which is manifested not only in a decrease in the volume of products and services provided in various sectors of the economy, but also in a change the needs of the population in connection with the rise in prices, the expected decrease in the level of income and the possible loss of work, massive bankruptcy of enterprises, etc. The coronavirus pandemic has revealed several economic, social, and humanitarian problems associated with changes in the lifestyle, work, and rest of the population.

\footnotetext{
*Corresponding author: mtsoi@mail.ru
} 
This has led to the fact that, since the spring of 2020, the provision of recreational and tourist services to residents of all regions of the Russian Federation has become almost impossible. Similar problems exist in many other countries of the world, especially those whose economy depends significantly on the efficiency of the tourism sector and is based on the use of natural resource potential [1]. At the same time, it is important to understand that during the implementation of new or modified programs for the development of the tourism industry, the great importance is to adhere to the concept of "sustainable development of territories", which is largely aimed at both reducing the negative impact of events like the COVID-19 pandemic, but also at stimulating the satisfaction of everincreasing needs of tourists in conditions of limited resources [2]. However, in the current situation, many regions have not been able to adapt and have not demonstrated the ability to provide high-quality tourist and recreational services. Difficulties also arose in the development and implementation of strategic approaches aimed at the sustainable development of tourism-recreation. This is largely because now there are no universal and effective methods for assessing the recreational-tourist potential of local territories, which makes the decision-making process on the development of certain directions of tourism rather complicated and ambiguous both at the global and local levels. (for specific organizations that produce tourism products and provide tourism services).

Insufficient efficiency of existing methods for assessing potential is caused, as a rule, by the fact that they do not consider the specifics of the needs of potential tourists. Certain categories of the population choose specific types of tourist-recreational services, which makes it possible to single out the appropriate segments of consumers and develop the most effective targeted offers for each of them. Consequently, there is a need to form a methodological approach that synthesizes methods for assessing the tourist-recreational potential of local territories (municipalities and urban districts) and the real needs for tourist-recreational services among the population of the region.

The development of a methodological approach to the assessment of the touristrecreational potential of local territories, considering the recreational needs of the population is chosen as the goal of the presented study. To achieve this goal, it is necessary to synthesize approaches to the analysis of regional tourist markets from the point of view of studying the needs of the population in tourist-recreational services and comparing them with the possibilities of the tourist potential of territories.

\section{Materials and Methods}

Considering modern trends in tourism development, corresponding to the concept of sustainable development, the following needs of modern tourists can be distinguished: ensuring the safety of tourist trips; reorientation of tourist flows towards safe, "green" tourism; visiting places with a favorable ecological and epidemiological situation, located in an accessible area; placement using modern means of less dense placement of the desired level of comfort, etc. All this requires the identification and detailed study of the factors influencing consumer demand and forming the tourist potential of local territories. This will be especially important for planning and forecasting the development of tourism at the level of the region of permanent residence of tourists.

When assessing the tourist-recreational potential of territories, as a rule, various approaches are used: recreational-geographical, ecological, marketing, cadastral, geoinformation, cluster, eco-system, etc. [3]. However, they do not allow to fully cover the entire range of factors and conditions that contribute to the development of tourism at the local level, and often do not consider the needs of the population living in the region. In this regard, the relevance of studying this issue at the level of local territories increases to meet the recreational needs of various groups of the population. Modern methods for assessing 
the tourist-recreational potential of territories should consider the unevenness of the location of natural, climatic, historical, cultural, and socio-economic resources, determine the correspondence between the elements of the tourist-recreational potential that determine the tourist offer, and the needs of the population in tourist-recreational services $[4,5]$.

To implement various goals of economic development on a global and regional scale, methods of assessing various elements of the resource potential of territories are used (Al Mamun A., Mitra SA, Abrham J., Ashouri P., Fariyadi Sh., Kayode IB, Ayodele IA, Shamsoddini A., Gadakh Bharat L, Jaybhaye Ravindra G., Nalawade Pravin M. et al. [610]).

Traditional methods of assessing the tourist-recreational potential are multifaceted, but they do not always correspond to the principles of sustainable development of territories. In tourism, the factors and threats to sustainable development are local in nature, depend on the specificity, which has its own unique economic, environmental, and social characteristics. Economic and social development should be based on the principles of sustainable development, maintain high levels of tourist satisfaction, provide awareness of sustainability issues, and promote sustainable tourism practices. At the same time, local government should play a key role in organizing tourism (Mayer D., Helfman G., Butler R., Sharpley R., Fabic M.M., Jurdana LS, Croatia, etc.) [1, 2, 11]

\section{Results and Discussion}

The analysis showed that for the purpose of sustainable development and careful use of tourist resources, tourism management bodies need a methodology for assessing the touristrecreational potential of local territories, considering the needs of the population, based on methods of expert assessment, multivariate statistical analysis, and economic and mathematical modeling.

To achieve the set goals, it is proposed to develop an integrated method based on the synthesis of recreational-geographical, marketing, cluster approaches, as well as including economic and mathematical modeling and cross-classification.

The general structure of the proposed methodology can be represented as follows:

1. Assessment of the tourist-recreational potential of local areas. Allocation of classes of territories by types of services.

2. Revealing the needs of the region's population in tourist-recreational services. Formation of homogeneous segments of consumers of tourist-recreational services.

3. Analysis of the correspondence between the needs of the population and the classes of local territories - administrative-territorial entities.

4. Use of modern statistical technologies to identify the most promising directions for the development of the tourism sector; determination of territorial entities for which investment in infrastructure development is most effective; improvement of the services provided, in accordance with the real needs of the population.

5. 5.Development of recommendations for territorial planning and directions for the development of types of tourism-recreation of a certain territory.

At the first stage, it is planned to analyze the macro indicators of local territories to determine and build a classification by the type of tourism-recreation services.

At the second stage, the opinion on the needs for tourism-recreation services, both target and special groups of the population, such as people with special needs, representatives of different cultures and / or population groups, etc. is studied based on marketing research, including in-depth interviews, focus groups and offline and online questionnaires.

The third stage is cross-analysis (analysis of correspondences, joint analysis, etc.), which makes it possible to identify the correspondence between the available resources and the emerging needs of the population. In addition, based on the identified correspondences, 
a rating assessment of the potential of the territories is formed, which makes it possible to characterize both the current and future level of sustainable tourism development in the regions.

At the fourth stage, an assessment of the development potential of certain territorial entities is carried out, based on the methods of multidimensional scaling, factor and cluster analysis, methods of expert assessment, methods of visualizing multidimensional information, etc., groups of territories that are similar in their characteristics are distinguished; the main mechanisms of sustainable tourism development for the territories under consideration are identified and the most significant of them are determined.

At the fifth stage, scenarios of sustainable development of the potential of territories are developed, which are aimed at forming methodological and practical recommendations for building a model of sustainable development of tourist territories.

The developed methodological approach allows to solve the following tasks:

- to reveal the real needs of the population of the region for recreational-tourist services.

- to assess the resource potential of local territories from the standpoint of the possibilities of providing tourist-recreational services in areas of a particular territory for isolated groups of consumers.

- to establish correspondences between the identified potential and the existing needs for tourist and recreational services.

- to develop specific recommendations for the sustainable development of the territory within the framework of improving the tourist-recreational activities of both state and private enterprises.

\section{Conclusions}

The bifurcation point in which tourism is located on a global scale now already suggests that the tourism sector will not be the same. In this regard, it is necessary to radically revise the structure of the tourist offer in favor of the development of recreational tourism to meet the changed needs of residents of certain territories, aimed at developing an economically efficient model for the sustainable development of tourist areas.

Currently, sustainable tourism, including natural oriented, is a powerful lever of economic growth of territories, which allows improving the overall environmental situation, implementing technologies for the careful use of natural potential, improving the quality of life of the population, creating new jobs, etc. Development of the recreational potential of the territory contributes to the formation and improvement of tourism infrastructure, contributes to economic diversification, establishment partnerships between government bodies and private business, preservation of historical and cultural heritage, etc.

Development and applying of this methodological approach will allow actively assess the tourism potential of local territories, considering the recreational needs of the population and the priorities of tourism development.

The results of the assessment of the potential elements allows to use effectively the available natural recreational resources to meet the constantly changing diverse needs of tourists who choose to rest on their territory.

\section{References}

1. Resolution adopted by the General Assembly on December 21 (2020) https://undocs.org/ 
2. UNWTO (2021) https://www.unwto.org/

3. E.O. Ushakova, M.E. Tsoy, V.Y. Shchekoldin, IOP Conference Series: Earth and Environmental Science, 204, 012046 (2018)

4. E.O. Ushakova O., A.V. Dubrovsky, V.N. Moskvin., S.A. Vdovin, IOP Conference Series: Earth and Environmental Science, 459, 062049 (2020)

5. N.V. Rozumnaya, M.E. Tsoy, V.A. Nazarkina, IOP Conference Series: Earth and Environmental Science, 204, 012039 (2018)

6. A. Al Mamun, S.A. Mitra. West Bengal (India) International Journal of Scientific and Research Publications, 9 (2), 1 (2012)

7. P. Ashouri, Sh. Fariyadi, Journal of Environmental Studies, 36 55, 1 (2010)

8. I.B. Kayode, I.A. Ayodele, Obeche Journal, 30 (1), 381 (2012)

9. A. Shamsoddini, Open Journal of Ecology, 80 (2015)

10. Gadakh Bharat L., Jaybhaye Ravindra G., Nalawade Pravin M, International Journal of Research in Geography (IJRG), 1 (1), 8 (2015)

11. M. Mičetić Fabić, D. Smolčić Jurdana, Tourism \& Hospitality Industry Congress Proceedings, 260 (2018) 